\title{
CORRIGENDUM
}

\section{Gum arabic establishes prebiotic functionality in healthy human volunteers in a dose-dependent manner - CORRIGENDUM}

\author{
Wim Calame, Antje R. Weseler, Christer Viebke, Cal Flynn and André D. Siemsma
}

doi:10.1017/S0007114508981447, Published by Cambridge University Press, 09 May 2008.

Regrettably two errors occurred in the above publication ${ }^{(1)}$. In Table 1, p. 1270. 'Amino acid sequence' should read 'nucleotide sequence':

Table 1. Primers used within the present study to quantify the various (groups of) bacteria by means of real-time PCR

\begin{tabular}{llc}
\hline (Group of) bacteria identified & \multicolumn{1}{c}{ Nucleotide sequence } & Reference no. \\
\hline (I) Bifidobacteria spp. (243 bp) & $\begin{array}{l}\text { Forward: 5'-TCGCGTC(C/T)GGTGTGAAAG-3' } \\
\text { Reverse: 5'-CCACATCCAGC(A/G)TCCAC-3' }\end{array}$ & 14 \\
(II) Lactobacilli spp. (341 bp) & $\begin{array}{l}\text { Forward: 5'-AGCAGTAGGGAATCTTCCA-3' } \\
\text { (III) Bacteroides spp. (140 bp) }\end{array}$ & $\begin{array}{l}\text { Reverse: 5'-CACCGCTACACATGGAG-3' } \\
\text { Forward: 5'-GGTGTCGGCTTAAGTGCCAT-3' }\end{array}$ \\
(IV) Clostridium difficile (157 bp) & $\begin{array}{l}\text { Reverse: 5'-CGGA(C/T)GTAAGGGCCGTGC-3' } \\
\text { Forward: 5'-TTGAGCGATTTACTTCGGTAAAGA-3' }\end{array}$ & 14 \\
(V) Enterococci spp. (144 bp) & $\begin{array}{l}\text { Reverse: 5'-CCATCCTGTACTGGCTCACCT-3' } \\
\text { Forward: 5'-CCCTTATTGTTAGTTGCCATCATT-3' }\end{array}$ & \\
& Reverse: 5'-ACTCGTTGTACTTCCCATTGT-3' & \\
\hline
\end{tabular}

and in the Discussion on p. 1274, the second sentence in the second paragraph should read:

There are various limiting factors in this approach: not only the correlation in the number and composition of bacteria between a faecal slurry sample and the gut lumen, but also the validity of the primers used: how reliable is the binding of the used nucleotide array to specific DNA in the stool.

\section{References}

1. Calame W, Weseler AR, Viebke C, et al. (2008) Gum arabic establishes prebiotic functionality in healthy human volunteers in a dose-dependent manner. Br J Nutr 100, 1269-1275. Published by Cambridge University Press, 09 May 2008, doi:10.1017/S0007114508981447.

2. Rintilä T, Kassinen A, Malinen E, et al. (2004) Development of an extensive set of 16S rDNA-targeted primers for quantification of pathogenic and indigenous bacteria in faecal samples by real-time PCR. J Appl Microbiol 97, 1166-1177. 